\title{
Determination of Zinc, Copper, Cadmium and Lead in Serum of Patients with Acute Leukemia
}

\author{
Mahmoud. A. Ghandour ${ }^{1}$, Ahmad F. Thabet ${ }^{2}$ and Rafallah M.A. Mohamed ${ }^{3}$ \\ ${ }^{1}$ Chemistry Department, Faculty of Science, Assiut University, Assiut-71516 - Egypt \\ ${ }^{2}$ Department of internal medicine, Faculty of Medicine Assiut Universty, Assiut-71516- Egypt \\ ${ }^{3}$ Department of Chemistry, Faculty of Science, Misurata University, Misurata - Libya
}

\begin{abstract}
The relations between malignant hematological diseases and trace heavy metals in blood have not been understood clearly. Alterations in serum $\mathrm{Zn}$ and $\mathrm{Cu}$ levels may frequently occur in many neoplastic diseases, including leukemia. Therefore, it is necessary from an analytical point of view to develop sensitive and economical methods for the determination of trace amount of heavy metals and the relationship between changes in concentrations of these metals and the development of hematological malignancies. Differential Pulse Stripping Voltammetry (DPAdSV) is relatively inexpensive and is one of the most sensitive and selective techniques in the determination of trace amounts of metals. The levels of heavy metals such as $\mathrm{Zn}, \mathrm{Cu}, \mathrm{Pb}$ and $C d$ were determined in the serum of 20 patients with acute leukemia before initial chemotherapeutic treatment and compared to 15 apparently health control group using two different analytical techniques; (DPAdSV) and inductively coupled plasma optical emission spectrometry (ICP-OES). The selection criteria for the patients and controls were the lack of recent blood transfusion history and taking any medication with mineral supplement. The Serum levels of $\mathrm{Cu}, \mathrm{Zn}$ and $\mathrm{Cd}$ were significantly lower with acute leukemia than controls ( $p=0.003$, $p=0.035, p=0.014$, respectively), while Pb was insignificantly elevated ( $p=0.381)$. Conclusion: In this study, we found the levels of $\mathrm{Cu}, \mathrm{Zn}$ and $\mathrm{Cd}$ to be lowered and of lead to be elevated in patients with acute leukemia. Further studies are needed to clarify the role of these elements in pathogenesis of acute leukemia. And also a comparative study was carried out between the results using DPAdSV and ICP-OES techniques, which are in very good agreement.
\end{abstract}

Keywords-Acute Leukemia, Serum, Stripping Voltammetry, Zinc

\section{Introduction}

Acute leukemia is a clonal malignant disorder affecting all age groups. It is characterized by the accumulation of immature blast cells in the bone marrow. This results in bone marrow failure, reflected by peripheral blood cytopenias and circulating blast cells. In most cases the etiology is not obvious, but internal and external factors associated with damage to DNA can predispose to acute leukemia [1].Blood is the transport medium for the nutrients and trace metals to and from the tissues and, therefore, provides rapid and reliable information about the trace metal metabolism in human body [2,3].Several studies have been reported in the recent years regarding the trace metal evaluation in the body liquids but because of natural significance and ease of sampling, blood is the most commonly used specimen. Consequently, whole blood, serum and plasma have been used in biological research for the determination of trace metal status of individuals and groups [4-6].

Zinc plays a key role in cell membrane integrity and is a component of more than 300 different enzymes for the functioning of the cellular activity and the metabolism of proteins, lipids and carbohydrates [7]. Zinc deficiency can produce growth retardation, anorexia, delayed sexual maturation, anemia, mental retardation, impaired visual and immunological function, etc., while excessive $\mathrm{Zn}$ intake might interfere with the $\mathrm{Cu}$ absorption, impair the lymphocyte and neutrophil function or reduce the serum concentration of the high density lipoprotein cholesterol [8]. Copper is an economically important element that is found in only trace quantities in the Earth's crust. For both plants and animals it is required as a trace nutrient, but excessive amounts are toxic [9]. High amounts of copper in the human body can cause stomach and intestinal distress such as nausea, vomiting and diarrhea. Copper and zinc have been associated with normal lymphocyte maturation and regulation of immune function. Low levels of these minerals have been demonstrated in a variety of dysfunctions of the immune system [10].Serum concentrations of copper and zinc are modified in some cancers; serum copper concentrations may be increased in some leukemias [11], and lymphomas [12], whereas variations of zinc concentrations have been demonstrated in leukemia. The levels of $\mathrm{Cd}$ and $\mathrm{Pb}$ in the human body have a great toxicological significance being responsible for a number of health impairments. In particular, Cadmium is known as a highly toxic metal that represents a major hazard to the environment and humans. The extremely long biologic half-life (30-35 years) makes it a cumulative toxicant, with liver and kidney as the main organs of accumulation [13]; therefore, long-term past exposure could still result in direct toxic effects [14]. The toxicity 
of this metal contributes to a large variety of health conditions, including the most important diseases such as heart disease, cancer, and diabetes [15-19].

Lead is known to be a toxic metal that accumulates in the human body throughout the lifetime. Its cumulative poisoning effects are serious hematological damage, brain damage, anemia, and kidney malfunctioning [20]. Imbalances in the optimum levels of these trace elements may adversely affect biological processes and are associated with many fatal diseases, such as cancer. There are several reports on serum trace element levels in malignant diseases including leukemia and lymphomas [21]. But, there are contradictory data between the previous studies, done related to the trace elements state in acute leukemia [22].

\section{Study Subjects}

\section{Experimental}

This study included twenty patients were newly diagnosed as acute leukemia ( 9 females and 11 males) aged between 20 and 50 years. Diagnosis of acute leukemia based on symptoms, physical finding as well as complete blood picture with total and differential

* Corresponding author. E-mail address: ghandour0100@yahoo.com

leucocytic count, bone marrow aspirate and immunophenotyping when needed. All the patients were enrolled in the study before receiving any chemotherapeutic agents. The selection criteria for the patients and controls were the lack of recent blood transfusion history and taking any medication with mineral supplement. The patients were recruited from clinical hematology unit, Internal Medicine department, Assiut University Hospital. The control group consisted of fifteen healthy subjects ( 6 females and 9 males) aged between 20 and 45 years were chosen for our study and approved by the Ethic Committee.

\section{Sample collection and processing}

Blood samples $(5 \mathrm{ml})$ of patients were collected by venous puncture. Blood samples of control were collected from the same areas of patients.. The puncture site was cleaned to remove any expected contamination before sampling. Separate and disposable sterilized plastic syringes were used for blood collection. The blood sample was left standing for $1 \mathrm{~h}$ to coagulate; serum was separated at $3500 \mathrm{rpm}$ centrifugation for $10 \mathrm{~min}$, transferred to $5 \mathrm{ml}$ polystyrene tube, and stored at $-5^{\circ} \mathrm{C}$ until analysis.

\section{Reagents and solutions}

All reagents are of analytical grade. Solution of each $\mathrm{Zn}(\mathrm{II}), \mathrm{Cu}(\mathrm{II}), \mathrm{Pb}(\mathrm{II})$ and $\mathrm{Cd}(\mathrm{II})$ were prepared respectively by dissolving the required amounts of $\mathrm{Zn}\left(\mathrm{NO}_{3}\right) \cdot 3 \mathrm{H}_{2} \mathrm{O}, \mathrm{Cu}\left(\mathrm{NO}_{3}\right)_{2} \cdot 2 \mathrm{H}_{2} \mathrm{O}, \mathrm{Pb}\left(\mathrm{NO}_{3}\right)$ and $\mathrm{Cd}\left(\mathrm{NO}_{3}\right)_{2} \cdot 4 \mathrm{H}_{2} \mathrm{O}$ in bidistilled water.

\section{Instrumentation}

All glassware was soaked in $10 \%(\mathrm{v} / \mathrm{v}) \mathrm{HNO}_{3}$ for $24 \mathrm{~h}$ and rinsed three times with distilled water and then in redistilled water before use:

Anodic differential pulse stripping voltammograms were recorded by polarographic Analyzer stripping voltammeter Model 264 A (EG\&G, Princeton Applied Research; Princeton, NJ, USA), coupled with a PAR 303 A Static Mercury Drop Electrode (SMDE; drop size: medium, area of the drop: $0.014 \mathrm{~cm} 2$ ). The polarographic cell bottom (PAR Model $\mathrm{K} \mathrm{0060)} \mathrm{was} \mathrm{fitted} \mathrm{with} \mathrm{Ag} / \mathrm{AgCl}$ saturated $\mathrm{KCl}$, reference electrode, and platinum wire used as a counter electrode. A PAR 305 stirrer was connected to the 303 SMDE. A PAR Model RE 0089 $\mathrm{X}-\mathrm{Y}$ recorder was used for recording the voltammograms. Before measurements the sample solution was deaereated by bubbling for 16 minutes with nitrogen. During measurements, an inert atmosphere over the solution was maintained by flushing with nitrogen. During the deposition step, the solution was stirred automatically, followed by a quiescent period of $15 \mathrm{sec}$ before scanning.

All the determinations were carried out by inductively coupled plasma optical emission spectrometry (ICP-OES). Thermo Fisher Scientific Announces Enhanced iCAP 6200 Optical Emission Spectrometer was used with the following operating conditions: Nebulizer Gas flow rates: $0.61 / \mathrm{min}$; Auxiliary Gas Flow: 0.5 1/min; Coolant Gas Flow: 12 1/min; Nebulizer Argon Flow: 0.6 1/min; Pumb Speed: 45 rpm; RF Forward Power: 1150 Prior to analysis.

- pH was measured with Hanna microprocessor pH model 211.

\section{Sample digestion}

One milliliter serum sample was wet digested in covered glass beaker containing a $10 \mathrm{~mL}(1: 1) \mathrm{HNO}_{3} /$ $\mathrm{HClO}_{4}$ acid mixture. The digest was transferred in to a $25 \mathrm{~mL}$ pre-cleaned measuring flask, diluted to the mark with double distilled water, and stored for analysis. Blank solution was treated and prepared in the same way as the samples. Each sample and each blank were prepared in triplicate. 
Analytical procedure: the following parameters were used to perform Differential Pulse Anodic Stripping Voltammetry (DPASV). Scan rate $10 \mathrm{mVs}^{-1}$ with duration for $1 \mathrm{sec}$ and pulse amplitude $(\Delta \mathrm{E}) 25 \mathrm{mV}$. For determination of $\mathrm{Zn}(\mathrm{II}), \mathrm{Cu}(\mathrm{II}), \mathrm{Pb}(\mathrm{II})$ and $\mathrm{Cd}(\mathrm{II})$ in blood serum in patients with acute leukemia and control in the same cell.

$5 \mathrm{~mL}$ of each sample solution and $1 \mathrm{~mL}$ of $0.1 \mathrm{M} \mathrm{HNO}_{3}$ solution as supporting electrolyte were transferred into the electrolysis cell and completed to $10 \mathrm{~mL}$ using bidistilled water $(\mathrm{pH} \sim 2)$. The solution was deaereated by passing pure nitrogen for $16 \mathrm{~min}$. The deposition potential were controlled at $-1.2,-0.25,-0.6$ and $-0.75 \mathrm{~V}$ vs. $\mathrm{Ag} / \mathrm{AgCl}$ sat'd $\mathrm{KCl}$ respectively and applied to a fresh mercury drop while the solution was stirred. After the deposition step and further $15 \mathrm{sec}$. (equilibrium time) the voltammogram was recorded.

Different concentration from the standard metal ion (individually) were added to the cell using an automatic pipette, while keeping the deposition time constant. The solution was stirred and purged with nitrogen for $30 \mathrm{sec}$. after each spike. The concentration of each $\mathrm{Zn}$ (II), $\mathrm{Cu}(\mathrm{II}), \mathrm{Pb}(\mathrm{II})$ and $\mathrm{Cd}$ (II) in the electrolytic cell was calculated in the sample solutions by using standard addition method, Then the concentration in $\mu \mathrm{g} / \mathrm{ml}$ of each blood serum in patients with acute leukemia and control were calculated and compared.

\section{Statistical Analysis:}

Statistical analyses were carried out using the SPSS statistical software package (SPSS for Windows version 13.0, SPSS Inc., Chicago, Illinois, USA). All results are expressed as mean and standard deviation (mean $\pm \mathrm{SD}$ ). A "p" value $<0.05$ was considered statistically significant.

\section{Results And Discussion}

This study included twenty patients were newly diagnosed as acute leukemia (AML: 15; ALL: 5), 9 females and 11 males aged between 20 and 50 years. Their clinical and laboratory data shown in table (1).

\section{Optimal conditions for the determination of $\mathrm{Zn}(\mathrm{II}), \mathrm{Cu}(\mathrm{II}), \mathrm{Pb}$ (II) and $\mathrm{Cd}(\mathrm{II})$ by $\mathrm{DPA}_{d} \mathrm{SV}$ technique}

Preliminary experiments have been carried out to investigate the effect of various operational parameters on the differential pulse anodic stripping response. The anodic peak currents were studied with respect to the supporting electrolyte compositions, $\mathrm{pH}$, deposition potential, scan rate and deposition time to optimize the conditions for analytical utility to obtain the highest peak signal for metal ions $\mathrm{Zn}$ (II), $\mathrm{Cu}$ (II), $\mathrm{Pb}$ (II) and $\mathrm{Cd}(\mathrm{II})$ in serum solution samples. It was noticed that, $0.01 \mathrm{M}$ nitric acid solution $(\mathrm{pH} \sim 2)$ gave promising results for the determination of $\mathrm{Zn}(\mathrm{II}), \mathrm{Cu}(\mathrm{II}), \mathrm{Pb}(\mathrm{II})$ and $\mathrm{Cd}(\mathrm{II})$ ions.

The effect of deposition potential of each metal ion was studied and it was observed that the highest and best shape peaks for $\mathrm{Zn}(\mathrm{II}), \mathrm{Cu}(\mathrm{II}), \mathrm{Pb}(\mathrm{II})$ and $\mathrm{Cd}(\mathrm{II})$ were at deposition potentials $-1.2,-0.25,-0.6$ and -0.75 $\mathrm{V}$ vs. $\mathrm{Ag} / \mathrm{AgCl}$ sat'd $\mathrm{KCl}$. respectively. The effective scan rate which gives a suitable peak height of each metal was $10 \mathrm{mv} / \mathrm{sec}$.

The effect of deposition time on the oxidation peak signals of these metal ions was examined. Fig. 1 show the differential pulse anodic stripping voltammograms of $\mathrm{Zn}$ (II) in blood serum of patients with acute leukemia in acid solution at different deposition times. The optimal deposition times were selected for these metal ions of all sample solutions in a manner that linear relation must be established between deposition times and current signals.

Concentration of $\mathrm{Zn}(\mathrm{II}), \mathrm{Cu}(\mathrm{II}), \mathrm{Pb}(\mathrm{II})$ and $\mathrm{Cd}(\mathrm{II})$ in blood serum of patients with acute leukemia and control as determined by stripping voltammetry technique and inductively coupled plasma optical emission spectrometry.

The results of $\mathrm{Zn}$ (II), $\mathrm{Cu}$ (II), $\mathrm{Pb}(\mathrm{II})$ and $\mathrm{Cd}(\mathrm{II})$ concentrations in blood serum of control and patients with acute leukemia as determined by $\mathrm{DPA}_{d} \mathrm{SV}$ and ICP-OES are presented in Table 2 The mean $\mathrm{Zn}$ (II), $\mathrm{Cu}$ (II), $\mathrm{Pb}(\mathrm{II})$ and $\mathrm{Cd}$ (II) concentrations in blood serum of patients with acute leukemia are $0.5606,0.8180,0,2336$ and $0.0102 \mu \mathrm{g} / \mathrm{ml}$, respectively, while in control are $0.753,0.4070,0.2988$ and $0.0297 \mu \mathrm{g} / \mathrm{ml}$, respectively The results of the studied $\mathrm{Zn}(\mathrm{II}), \mathrm{Cu}(\mathrm{II}), \mathrm{Pb}$ (II) and $\mathrm{Cd}(\mathrm{II})$ in blood serum of patients with acute leukemia and control are discussed as follows.

\section{Determination of $\mathbf{Z n}(\mathrm{II})$}

Fig. 2 represents the differential pulse anodic stripping voltammograms of zinc in blood serum sample solution of patients with acute leukemia in absence and in presence of added standard zinc solution in nitric acid solution of $\mathrm{pH} \sim 2$. On plotting of peak current against concentrations for twenty blood serum sample solutions of patients with acute leukemia and control in the same supporting electrolyte at the same conditions, straight lines are obtained. From the interceptions of these lines with the concentration axis at zero current signals, one can calculate the concentration of $\mathrm{Zn}(\mathrm{II})$ in each sample.

Our result shows that the mean serum zinc level was significantly lower in leukemia patients $(0.5606 \mu \mathrm{g} / \mathrm{ml})$ than in the healthy control $(0.9753 \mu \mathrm{g} / \mathrm{ml}$; Table 2; Fig. 6), with p value $=0.035$ (Table 3). 
Our results were in agreement with the majority of studies, which mostly showed lower level of zinc in leukemic patients than control, as in Zuo et al., 2006 [22] study who found that the mean $\mathrm{Zn}$ level of 0.642 $\mu \mathrm{g} / \mathrm{ml}$ in the blood serum of patients with acute leukemia was lower than that detected in the blood serum of controls $0.984 \mu \mathrm{g} / \mathrm{ml}$, and also with Demir et al., 2011 [23] study who reported that, the mean concentration of serum zinc $(0.494 \mu \mathrm{g} / \mathrm{ml})$ was lower in patients with leukemia than in controls $(1.108 \mu \mathrm{g} / \mathrm{ml})$.

Our results are in agreement with Schwartz, 1975 study [24] who reported that there are some data suggesting an association between the deficiency of $\mathrm{Zn}$ and the development of malignant disorders, and with Brown et al., 1980 study[25], that experimental results support towards slightly decreased zinc concentrations in malignant diseases,. Also our results are in agreement with Demir et al , 2011[23] and Sahin et al., 2000[26] in their study that showed decreases in $\mathrm{Zn}$ levels in patients with acute leukemia when compared with controls

\section{Determination of $\mathrm{Cu}(\mathrm{II})$}

Fig. 3 shows the differential pulse anodic stripping voltammograms of $\mathrm{Cu}(\mathrm{II})$ in blood serum sample of patients with acute leukemia spiked with different concentration of copper ions in nitric acid solution of $\mathrm{pH} \sim 2$. On plotting of $i_{p}$ vs. $\mathrm{Cu}$ (II) concentrations for all blood serum samples in the same supporting electrolyte at the same conditions, straight lines are obtained (standard addition method). From the interceptions of these lines with the concentration axis at zero current signals, one can calculate the concentration of $\mathrm{Cu}(\mathrm{II})$ in each sample. The mean serum copper level in patients with acute leukemia $(0.818 \mu \mathrm{g} / \mathrm{ml})$ was significantly higher than that found in control $(0.407 \mu \mathrm{g} / \mathrm{ml})$ as shown in Table 2; Fig. 6, with $\mathrm{P}$ value $=0.003$ (Table 3). Our result is in agreement with that of Zuo et al., 2006 [22], Demir et al., 2011 [23] and Akkuş et al., 1998 [27] in which the serum $\mathrm{Cu}$ level in patient with leukemia was significantly higher than that in controls. They found that the serum copper levels in patients with leukemia were 1.291, 1.226 and $5.251 \mu \mathrm{g} / \mathrm{ml}$ and in controls were $0.867,1.047$ and $1.150 \mu \mathrm{g} / \mathrm{ml}$ respectively.

our results are in agreement with Tessmer et al., 1972; [21] Carpentieri et al., 1986 [28] , Osman et al., 1983;[29] and Akkus et al., 1998 [27] studies in leukemic patients in which serum Cu levels have been found to be higher than those of controls. Also our results in agreement with Tessmer et al., 1972 [21] and Ilicin, 1971 [30] who suggested that serum copper would be a useful indicator for the extent of leukemia and malignant lymphoma, and might be a predictor for chemotherapy response and they added that remission is usually associated with the return of $\mathrm{Cu}$ levels to normal ranges.

\section{Determination of $\mathbf{P b}(\mathrm{II})$}

The differential pulse anodic stripping voltammograms of lead in blood serum sample solution of patients with acute leukemia in absence and in presence of standard lead ions is shown in Fig. 4. The plots of peak current against concentration, a straight lines are obtained. From the interception of these lines with the concentration axis at zero current signal gives the concentration of $\mathrm{Pb}$ (II) in the voltammetric cell for each sample. The mean serum lead level was lower in leukemic patients $(0.2336 \mu \mathrm{g} / \mathrm{ml})$ than in the control $(0.2988$ $\mu \mathrm{g} / \mathrm{ml}$ ) but without significant value as shown in Table 2; Fig. 6, with $\mathrm{P}$ value $=0.381$ (Table 3).

our results not in agreement with Demir et al , 2011 study [24] who found that levels of $\mathrm{Pb}$ were high in serum of acute leukemia compared to the control group but they add that literature data about $\mathrm{Pb}$ are more controversial and that no study evaluating $\mathrm{Pb}$ metal levels in acute leukemia in the literature. Further studies are necessary to interpret this finding better and to clarify the role of lead in the pathogenesis of leukemia.

\section{Determination of Cd(II)}

The differential pulse anodic stripping voltammograms of cadmium in blood serum sample solution of leukemia patient in absence and in presence of standard zinc ions is shown in Fig. 5. On plotting of peak current against concentrations for twenty blood serum sample solutions of leukemia patient and fifteen healthy control in the same supporting electrolyte at the same conditions, straight lines are obtained (standard addition method). From the interceptions of these lines with the concentration axis at zero current signals, one can calculate the concentration of $\mathrm{Cd}(\mathrm{II})$ in each sample.

The result shows that the mean serum cadmium level was significantly lower in leukemia patients $(0.0102 \mu \mathrm{g} / \mathrm{ml})$ than in the healthy control $(0.0297 \mu \mathrm{g} / \mathrm{ml}$; Table 2; Fig. 6), with P value $=0.014$ (Table 3).

our findings differs from that reported by Demir et al , 2011 study [24] who reported that Cd levels were higher in patients with leukemia compared to healthy group but he added that most studies have been made more in solid organ cancers and cadmium and they did not find a study that examined the association between acute leukemia and cadmium. More comprehensive studies are needed to clarify the pathogenesis of the acute leukemia and its relation to cadmium. 


\section{Comparison of the analytical methods}

A comparative study was carried out between the results of $\mathrm{Zn}(\mathrm{II}), \mathrm{Cu}(\mathrm{II}), \mathrm{Pb}(\mathrm{II})$ and $\mathrm{Cd}(\mathrm{II})$ in healthy blood serums obtained using differential pulse adsorptive stripping voltammetry(DPA $\left.\mathrm{d}_{\mathrm{d}} \mathrm{SV}\right)$ and inductively coupled plasma optical emission spectrometry (ICP-OES). A comparison of the results is shown in (Table 2). It was proved that the results obtained using stripping voltammetry for $\mathrm{Zn}(\mathrm{II}), \mathrm{Cu}(\mathrm{II}), \mathrm{Pb}$ (II) and $\mathrm{Cd}$ (II) $(0.969$, $0.407,0.2988$ and $0.0297 \mu \mathrm{g} / \mathrm{ml}$, respectively) nearly in agreement with those obtained using inductively coupled plasma optical emission spectrometry of the same elements $(1.080,0.519,0.349$ and $0.01297 \mu \mathrm{g} / \mathrm{ml}$, respectively) for healthy control. Generally, the data obtained by inductively coupled plasma optical emission spectrometry are in close agreement with those obtained by stripping voltammetry for some metals and slight differences for the others.However, the slight differences that may be found sometimes between both techniques are mainly due to the manipulation of the analyst and metal interferences in cases of inductively coupled plasma optical emission spectrometry while the standard addition method is used to perform the stripping voltammetry technique. The standard addition method is more accurate than the calibration curves, since additions of the standard analyst to the sample give precise results and minimize or even avoid the interferences usually inherent with the matrix analysis [31].

\section{Conclusion}

In this study we found the levels of copper, Zinc and cadmium to be lowered and of lead to be elevated in patients with acute leukemia. Further studies are needed to clarify the role of these elements in pathogenesis of acute leukemia. And also a comparative study was carried out between the results using DPAdSV and ICPOES techniques, which are in very good agreement.

\section{References}

[1] T. Everington, R. J. Liesner and A. H. Goldstone, The Acute Leukaemias. In 'ABC of Clinical Haematology, Ed Provan D (BMJ Books, London, 2003) 23-27.

[2] T. Wang, J. Fu, Y. Wang, C. Liao, Y. Tao and G. Jiang, Use of scalp hair as indicator of human exposure to heavy metals in an electronic waste recycling area, Envrion. Pollut., 157(24), 2009, 2445-2451.

[3] M. F. Robinson, J. M. McKenzie, C.D. Thomson and A. L. van Rij, Metabolic balance of zinc, copper, cadmium, iron, molybdenum and selenium in young New Zealand women, Brit. J. Nutr., 30, 1973, 195-205.

[4] M. Wilhelm, U. Ewers and C. Schulz, Revised and new reference values for some trace elements in blood and urine for human biomonitoring in environmental medicine, Int. J. Hyg. Environ. Health, 207, 2004, 69-73.

[5] M. Krachler, E.Rossipal and D. Micetic-Turk, Concentrations of trace elements in sera of newborns, young infants and adults, Biol. Trace Elem. Res., 68, 1999, 121-35.

[6] D. Smith, M.Hernandez-Avila, M.M. Tellez-Rojo, A. Mercado and H. Hu, The relationship between lead in plasma and whole blood in woman, Environ. Health Perspect., 110 (26), 2002, 3-8.

[7] G. Parkin, Chemistry. Zinc-zinc bonds: a new frontier, Science, 305, 2004, 1117-1118.

[8] D.G. Barceloux, Zinc, J. Toxicol. Clin. Toxicol., 37, 1999, 279-292.

[9] İ. Durukan, C. A. Sahin and S. Bektaș, Determination of copper traces in water samples by flow injection-flame atomic absorption spectrometry using a novel solidified floating organic drop microextraction method, Microchemical Journal, 98 (2), $2011,215-219$.

[10] O.A. Lukasewycz, and J.R. Prohaska, Immunization against transplantable leukemia impaired in copper-deficient mice, J. Nati. Cancer Inst., 69, 1982, 489-493.

[11] E.L.Andronikashvili and L.M. Mosulishvili, Human leukemia and trace elements. In: H. Sigel (ed.). Metal Ions in Biological Systems, New York: Marcel Dekker Inc. 10, 1980, 167- 206.

[12] Y. Cohen, R. Epelbaum, N. Haim, D.McShan, and O. Zinder, The value of serum copper levels in non-Hodgkin's lymphoma, Cancer, 53(2), 1984, 296-300.

[13] O. Yilmaz, Cadmium and lead levels in human liver and kidney samples obtained from Bursa Province, Int J Environ Health Res., 12, 2002, 181-185.

[14] P.L. Goering, M.P. Waalkes and C.D. Klaasen, Toxicology of cadmium. In: Goyer RA, editor. Handbook of experimental pharmacology: toxicology of metals. Biochemical effects, (New York: Springer-Verlag, 1994) 189-214.

[15] J.L. Peters, T.S. Perlstein, M.J. Perry, E. McNeely and J.Weuve, Cadmium exposure in association with history of stroke and heart failure, Environ Res., 110 ,2010, 199-206.

[16] J. Pius, Mechanism of cadmium carcinogenesis, Toxicol. Appl. Pharmacol., 238, 2009, 272-279.

[17] M.P. Waalkes, Cadmium carcinogenesis, Mutat., Res., 533, 2003, 107-120.

[18] G.F. Nordberg, Cadmium carcinogenesis and its relationship to other health effects in humans, Scand. J. Work Environ. Health., 19, 1993, 104-107.

[19] J. R.Edwards and W. C. Prozialeck, Cadmium: diabetes and chronic kidney disease, Toxicol. Appl. Pharmacol., 238, 2009, 289293.

[20] P. Liang and H. Sang, Determination of trace lead in biological and water samples with dispersive liquid-liquid microextraction preconcentration Analytical Biochemistry, 380(1), 2008, 21-25

[21] C.F. Tessmer, M. Hrgovic, F.B.Thomas, J.Wilbur and D.M. Mumford, Longterm serum copper studies in acute leukemia in children, Cancer; 30, 1972, 35-65.

[22] X.L. Zuo, J.M.Chen, X. Zhou, X. Z. Li, and G.Y.Mei, Levels of selenium, zinc, copper, and antioxidant enzyme activity in patients with leukemia Biological Trace Element Research, 114(1-3), 2006, 41-53.

[23] C. Demir, H. Demir, R. Esen, A. Sehitogullar, M. Atmaca and M. Alay, Altered Serum Levels of Elements in Acute Leukemia Cases in Turkey, Asian Pacific Journal of Cancer Prevention, 12, 2011, 3471-3474.

[24] M. K. Schwartz, Role of trace elements in cancer, Cancer Res., 35, 1975, 3481-3487

[25] D.A. Brown, K.W. Chatel, A.Y.Chan and B. Knight, Cytosolic levels and distribution of cadmium, copper and zinc in pretumorous livers from diethylnitrosamine-exposed mice and in non-cancerous kidneys cancer patients, Chem. Biol. Interact., 32, 1980, 13-27. 
[26] G. Sahin, U. Ertem, F. Duru, D. Birgen and N. Yüksek, High prevelance of chronic magnesium deficiency in T cell lymphoblastic leukemia and chronic zinc deficiency in children with acute lymphoblastic leukemia and malignant lymphoma, Leuk. Lymphoma, 39, 2000, 555-62.

[27] I. Akkuş, M. Gürbilek, Ü. Çalişkan, B. Kaptanoğlu and A. Üner, Blood and Fingernail Copper (Cu) and Magnesium (Mg) Levels of Children With Acute Lymphoblastic Leukemia, Tr. J. of Medical Sciences, 28, 1998, 155-156.

[28] U.Carpentieri, J.Myers, L.Thorpe, C.W. Daeschner and M.E. Haggard, (1986). Copper, zinc, and iron in normal and leukemic lymphocytes from children, Cancer Res., 46, 1986, 981-984.

[29] S. Osman, A.Gürgey, V.P.Zamani and C. Altay, Changes in serum elements of childhood acute lymphoblastic leukemia before and during therapy, Turk. J. Pediatr., 25, 1983, 233-43.

[30] G. Ilicin, Serum copper and magnesium levels in leukemia and malignant Iymphoma, Lancet, 2,1971, 1036-1037.

[31] A.D. Eaton, L.S.Clesceri and A.E. Greenberg, Standard methods for the examination of water and waste water, USA, 1995

Table (1): Clinical (symptoms and signs) and laboratory data of studied patients

\begin{tabular}{|c|c|c|c|}
\hline \multicolumn{2}{|c|}{ Clinical presentations } & \multicolumn{2}{|c|}{ Laboratory data } \\
\hline Symptoms and signs & $\begin{array}{l}\text { Number and } \\
\text { percentage of total } \\
(20 \text { patients })\end{array}$ & Parameters & Mean \pm SD \\
\hline $\begin{array}{c}\text { Fever } \\
\text { Intermediate grade } \\
\text { High grade }\end{array}$ & $\begin{array}{c}7(35 \%) \\
13(65 \%)\end{array}$ & $\begin{array}{c}\text { WBC Count }\left(\times 10^{9} / \mathrm{L}\right) \\
\text { ANC }\left(\times 10^{9} / \mathrm{L}\right)\end{array}$ & $\begin{array}{c}47.3 \pm 2.37 \\
1.4 \pm 0.1\end{array}$ \\
\hline Pallor & $18(90 \%)$ & Hemoglobin level (g/dl) & $7.56 \pm 0.283$ \\
\hline Jaundice & $2(10 \%)$ & $\begin{array}{l}\text { AST(IU/L) } \\
\text { ALT(IU/L) }\end{array}$ & $\begin{array}{l}36.7 \pm 0.78 \\
39.1 \pm 0.97\end{array}$ \\
\hline $\begin{array}{c}\text { Bleeding tendency } \\
\text { Epistaxis } \\
\text { Per gums } \\
\text { Per rectum } \\
\text { Purpura } \\
\text { Vaginal bleeding }\end{array}$ & $\begin{array}{c}3(15 \%) \\
4(20 \%) \\
1(5 \%) \\
12(60 \%) \\
1(5 \%)\end{array}$ & Platelet Count $\left(\times 10^{9} / \mathrm{L}\right)$ & $65.8 \pm 3.46$ \\
\hline $\begin{array}{c}\text { Hepato-splenomegally } \\
\text { Lymphadenopathy }\end{array}$ & $\begin{array}{l}8(40 \%) \\
9(45 \%)\end{array}$ & Creatinine (mg/dl) & $0.93 \pm 0.023$ \\
\hline
\end{tabular}

WBC : White blood cell.

ANC: Absolute neutrophil Count.

AST: Aspartate transaminase.

ALT :Alanine transaminase 


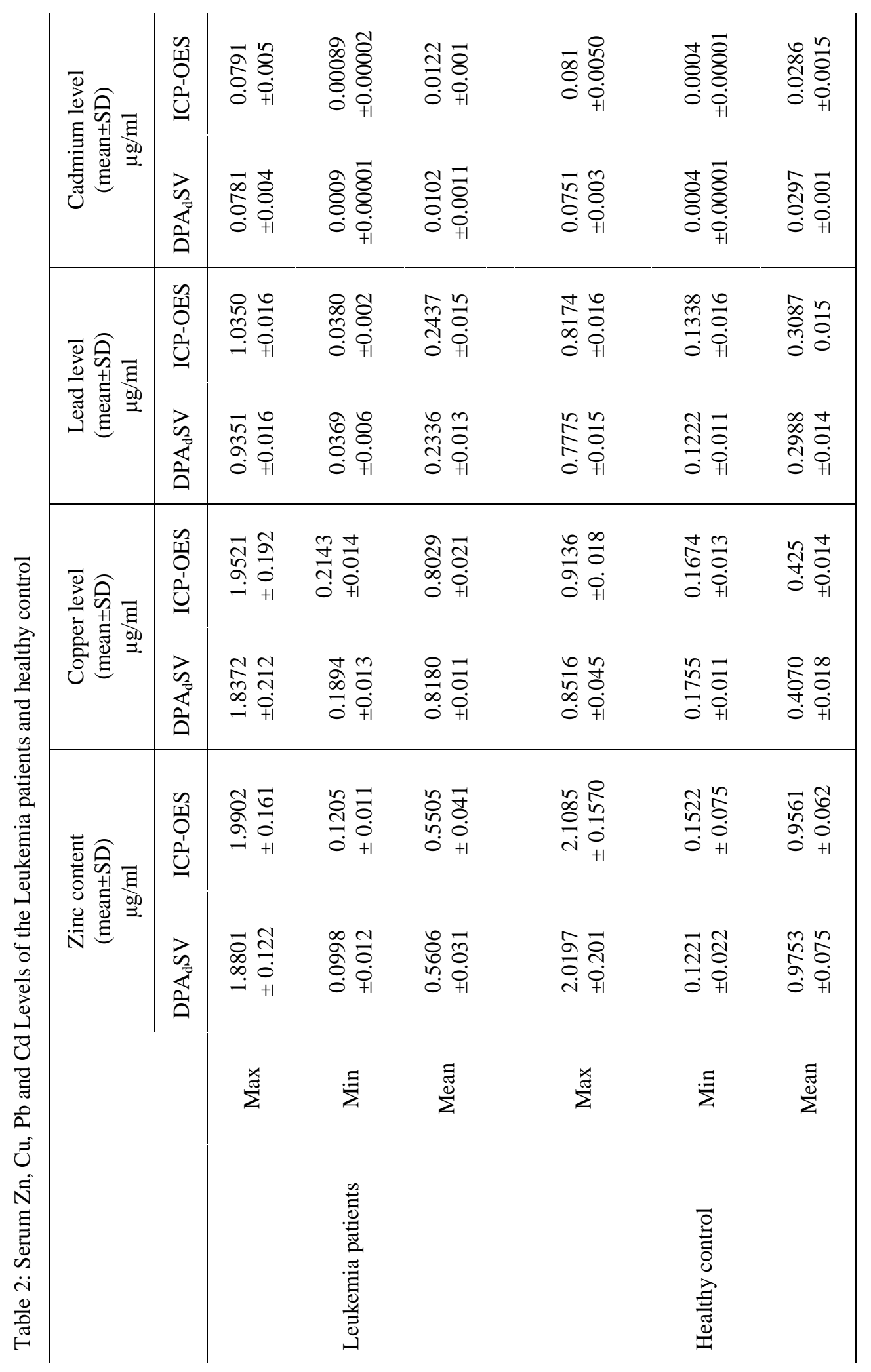


Table 3. Serum $\mathrm{Zn}, \mathrm{Cd}, \mathrm{Pb}$ and $\mathrm{Cu}$ Levels of the Participants using $\mathrm{DPA}_{\mathrm{d}} \mathrm{SV}$

\begin{tabular}{|c|c|c|c|}
\hline Parameters & Patients $(\mathrm{n}=20)$ & Controls $(\mathrm{n}=15)$ & $\mathrm{P}$ \\
\hline $\mathrm{Zn}(\mu \mathrm{g} / \mathrm{ml})$ & $0.561 \pm 0.497$ & $0.969 \pm 0.599$ & $\mathrm{P}=0.035$ \\
\hline $\mathrm{Cd}(\mu \mathrm{g} / \mathrm{ml})$ & $0.0102 \pm 0.0173$ & $0.0297 \pm 0.270$ & $\mathrm{P}=0.014$ \\
\hline $\mathrm{Pb}(\mu \mathrm{g} / \mathrm{ml})$ & $0.2336 \pm 0.216$ & $0.2988 \pm 0.213$ & $\mathrm{P}=0.381$ \\
\hline $\mathrm{Cu}(\mu \mathrm{g} / \mathrm{ml})$ & $0.8180 \pm 0.468$ & $0.4067 \pm 0.200$ & $\mathrm{P}=0.003$ \\
\hline
\end{tabular}

Zn, Zinc; Cd, Cadmium; Pb, Lead; Cu, Copper

All results are expressed as mean and standard deviation (mean $\pm \mathrm{SD}$ );

$\mathrm{P}$ value $<0.05$ was considered statistically significant

Table 4. Comparative mean of Serum $\mathrm{Zn}, \mathrm{Cd}, \mathrm{Pb}$ and $\mathrm{Cu}$ Levels of the controls using ICP \& $\mathrm{DPA}_{d} \mathrm{SV}$

\begin{tabular}{|c|c|c|c|}
\hline \multirow{2}{*}{ Parameter } & \multicolumn{2}{|c|}{ Control $(\mathrm{n}=15)$} & \multirow{2}{*}{ P } \\
\cline { 2 - 3 } & ICP & DPAdSV & $\mathrm{P}$ \\
\hline $\mathrm{Zn}(\mu \mathrm{g} / \mathrm{ml})$ & $1.080 \pm 0.599$ & $0.969 \pm 0.599$ & $\mathrm{P}=0.615$ \\
\hline $\mathrm{Cd}(\mu \mathrm{g} / \mathrm{ml})$ & $0.1297 \pm 0.027$ & $0.0297 \pm 0.027$ & $\mathrm{P}<0.001 *$ \\
\hline $\mathrm{Pb}(\mu \mathrm{g} / \mathrm{ml})$ & $0.399 \pm 0.213$ & $0.299 \pm 0.213$ & $\mathrm{P}=0.208$ \\
\hline $\mathrm{Cu}(\mu \mathrm{g} / \mathrm{ml})$ & $0.519 \pm 0.199$ & $0.4067 \pm 0.199$ & $\mathrm{P}=0.136$ \\
\hline
\end{tabular}

All results are expressed as mean and standard deviation (mean $\pm \mathrm{SD}$ ); $P$ value $<0.05$ was considered statistically significant

* Very highly significant

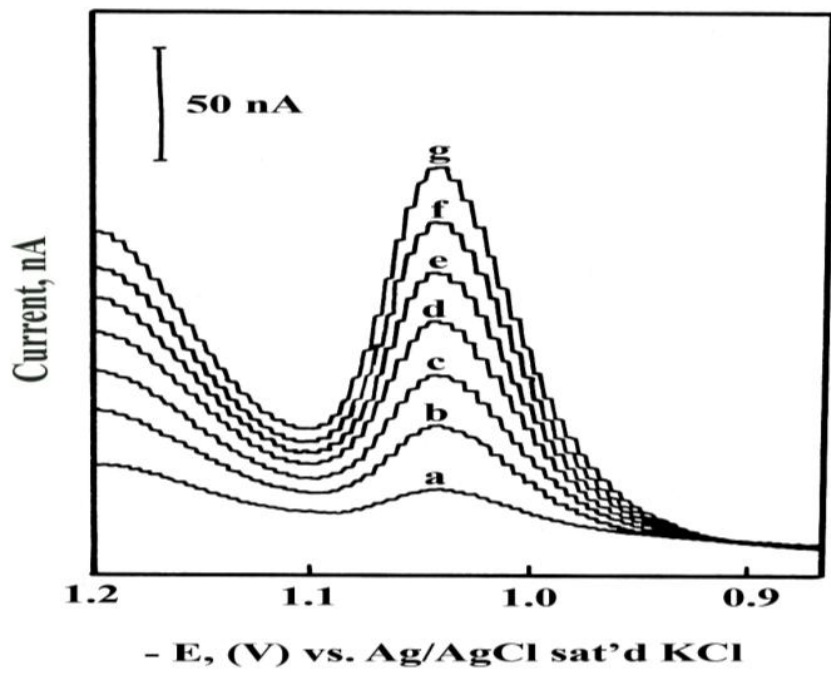

Fig. 1: DPAS Voltammograms of $\mathrm{Zn}$ (II) in blood serum of patients with acute leukemia in presence of $0.01 \mathrm{M}$ $\mathrm{HNO}_{3}$ acid solution, $\mathrm{pH} \sim 2$ at deposition potential $-1.2 \mathrm{~V}$ and different deposition times. (a) zero; (b) 10; (c) 20; (d) 30; (e) 40; (f) 50; (g) $60 \mathrm{sec}$. 


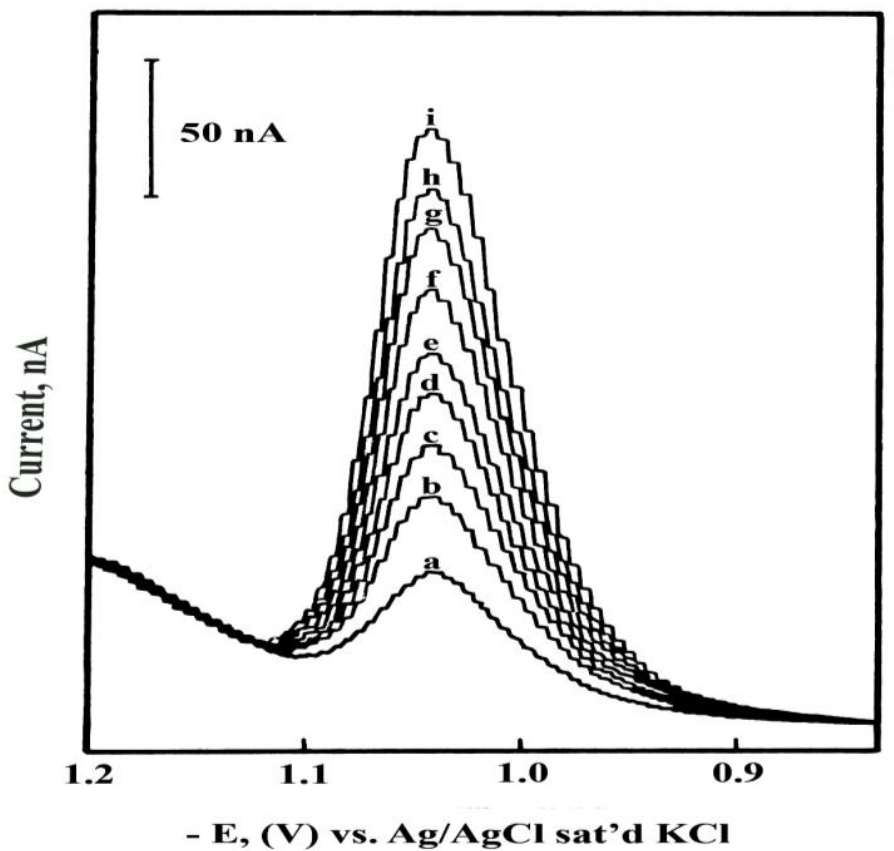

Fig. 2: DPAS Voltammograms of Zn(II) in blood serum sample of leukemia patient spiked with different concentrations of $\mathrm{Zn}$ (II) ions in $0.01 \mathrm{M} \mathrm{HNO3}$ acid solution, $\mathrm{pH} \sim 2$ at deposition potential $-1.2 \mathrm{~V}$ and

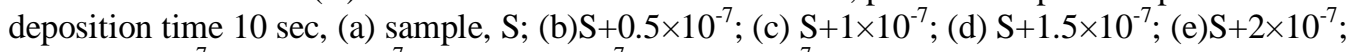
(f) $\mathrm{S}+2.5 \times 10^{-7}$; (g) $\mathrm{S}+3 \times 10^{-7}$; (h) $\mathrm{S}+3.5 \times 10^{-7}$; (i) $\mathrm{S}+4 \times 10^{-7} \mathrm{M} \mathrm{Zn}$ (II).

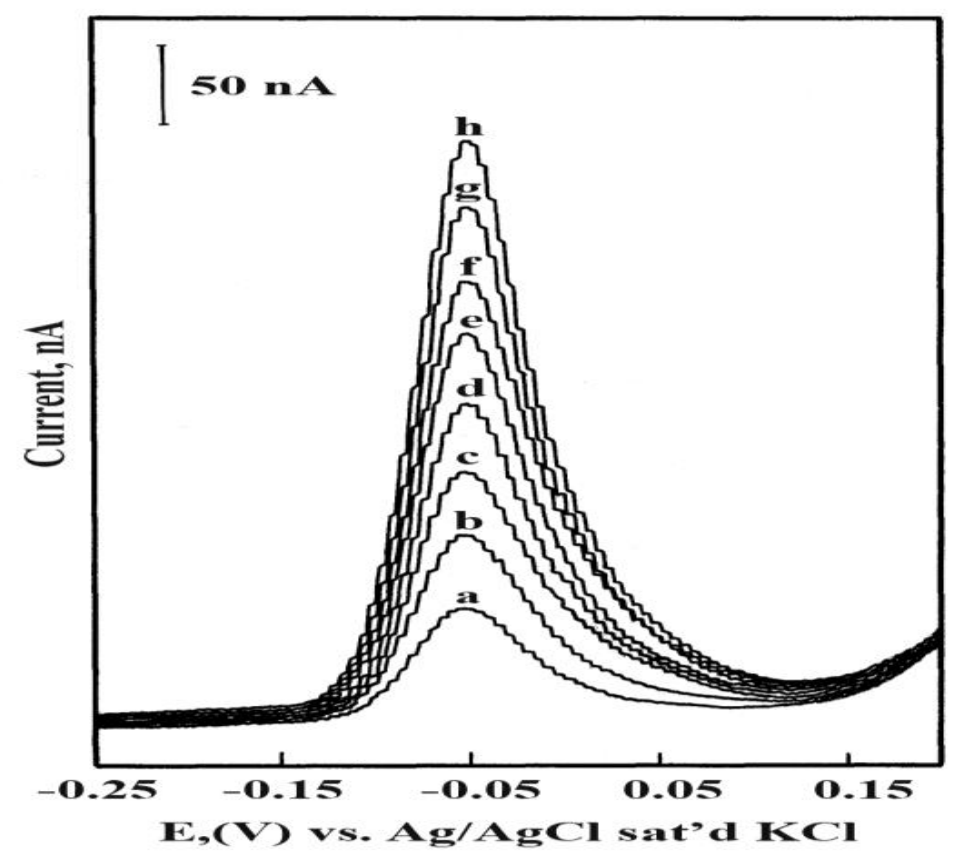

Fig. 3: DPAS Voltammograms of $\mathrm{Cu}(\mathrm{II})$ in blood serum sample of leukemia patient spiked with different concentrations of $\mathrm{Cu}(\mathrm{II})$ ions in $0.01 \mathrm{M} \mathrm{HNO}_{3}$ acid solution, $\mathrm{pH} \sim 2$ at deposition potential $-0.25 \mathrm{~V}$ and deposition time $30 \mathrm{sec}$, (a) sample, $\mathrm{S}$; (b) $\mathrm{S}+1.0 \times 10^{-7}$; (c) $\mathrm{S}+2.0 \times 10^{-7}$; (d) $\mathrm{S}+3.0 \times 10^{-7}$;(e) $\mathrm{S}+4.0 \times 10^{-7}$; (f) $\mathrm{S}+5.0 \times 10^{-7} ;$ (g) $\mathrm{S}+6.0 \times 10^{-7} ;$ (h) $\mathrm{S}+7.0 \times 10^{-7} \mathrm{M} \mathrm{Cu}$ (II). 


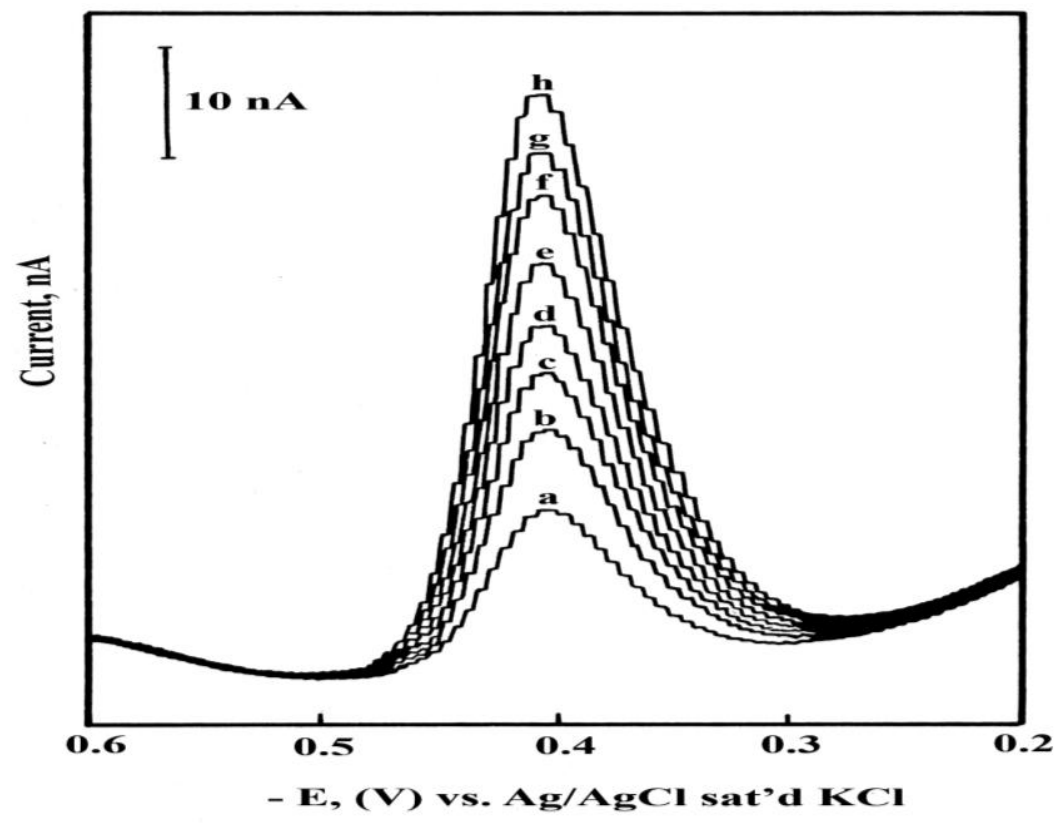

Fig. 4: DPAS Voltammograms of $\mathrm{Pb}(\mathrm{II})$ in blood serum sample of leukemia patient spiked with different concentrations of $\mathrm{Pb}(\mathrm{II})$ ions in $0.01 \mathrm{M} \mathrm{HNO}_{3}$ acid solution, $\mathrm{pH} \sim 2$ at deposition potential $-0.6 \mathrm{~V}$ and

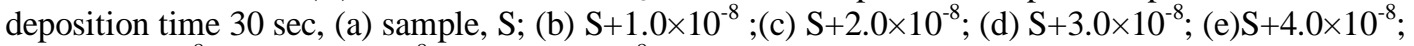
(f) $\mathrm{S}+5.0 \times 10^{-8}$; (g) $\mathrm{S}+6.0 \times 10^{-8}$; (h) $\mathrm{S}+7.0 \times 10^{-8} \mathrm{M} \mathrm{Pb}$ (II).

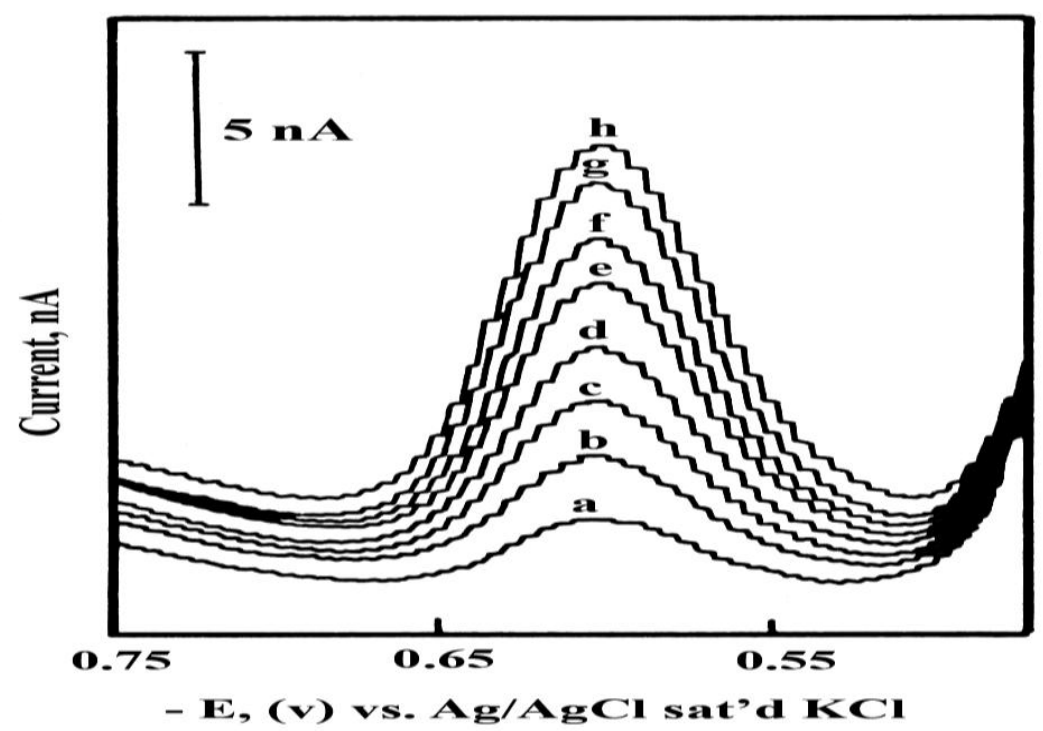

Fig. 5: DPAS Voltammograms of Cd(II) in blood serum sample of leukemia patient spiked with different concentrations of $\mathrm{Cd}(\mathrm{II})$ ions in $0.01 \mathrm{M} \mathrm{HNO}_{3}$ acid solution, $\mathrm{pH} \sim 2$ at deposition potential $-0.75 \mathrm{~V}$ and

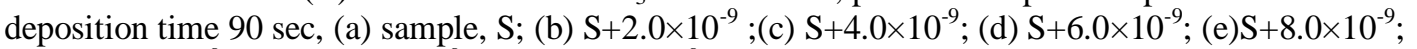
(f) $\mathrm{S}+10.0 \times 10^{-9}$; (g) $\mathrm{S}+12.0 \times 10^{-9}$; (h) $\mathrm{S}+14.0 \times 10^{-9} \mathrm{M} \mathrm{Cd}(\mathrm{II})$. 


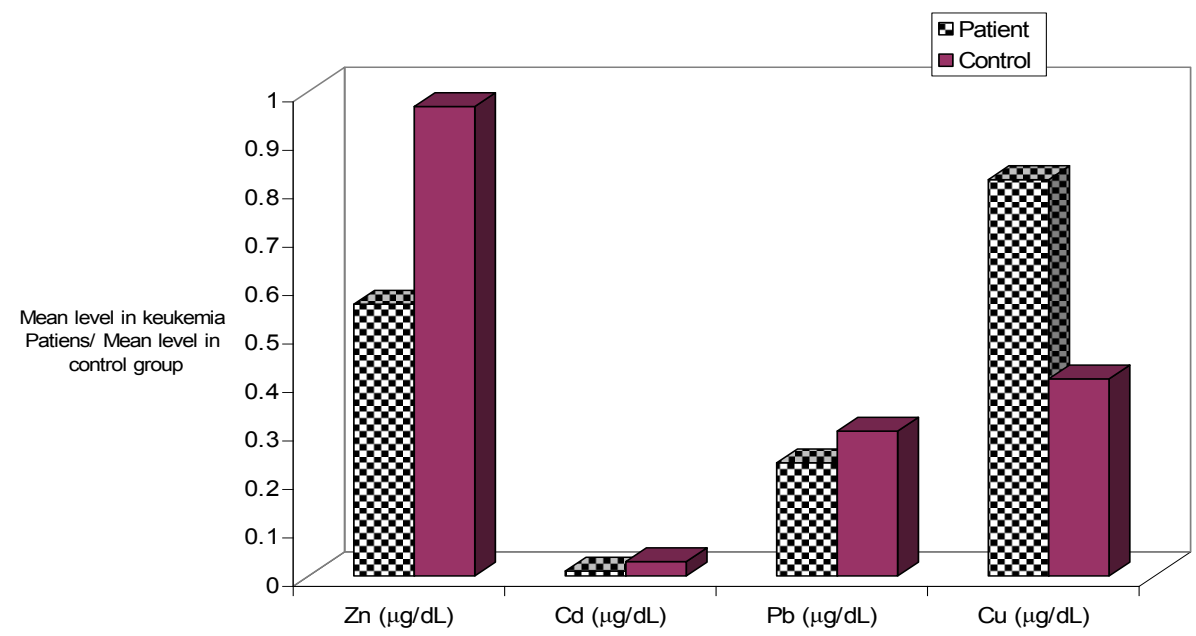

Fig. 6. Comparative mean of $\mathrm{Cu}, \mathrm{Zn}, \mathrm{Pb}$ and $\mathrm{Cd}$ levels in the serum of leukemic patients and controls using DPAdSV. 